А.Я. Хлебородов

И.М. Почицкая²,

О.С. Провоторова',

П.А. Скрипкович ${ }^{2}$

\title{
для производства
}

${ }^{1}$ Республиканское научно-производственное дочернее унитарное предприятие

«Институт овощеводства»

аг. Самохваловичи, Минский район, Республика

Беларусь

cucurbita@belniio.by, ol_provotorova@mail.ru

${ }^{2}$ Научно-практический центр Национальной академии наук Беларусипо продовольствию, г. Минск, Республика Беларусь

rkik-npc@mail.ru

Конфликт интересов: Авторы заявляют об отсутствии конфликта интересов.

Для цитирования: Хлебородов А.Я., Почицкая И.М., Провоторова О.С., Скрипкович П.А. Сортимент твердокорой тыквы (Cucurbita pepo L.) белорусской селекции для производства тыквенного масла. Овощи России. 2020;(6):41-46. https://doi.org/10.18619/2072-9146-2020-6-41-46

Поступила в редакцию: 23.04.2020

Принята к печати: 01.09.2020

Опубликована: 20.12.2020

Anatoly Ya. Khleborodov',

Irina M. Pochitskaya',

Olga S. Provotorova',

Polina A. Skripkovich ${ }^{2}$

1Republican research and production unitary subsidiary enterprise

"Institute for vegetable growing"

Samokhvalovichi, Minsk region, Belarus

cucurbita@belniio.by, ol_provotorova@mail.ru

2Scientific and practical center for foodstuffs of the National academy of sciences of Belarus Minsk, Belarus

rkik-npc@mail.ru

Conflict of interest. The authors declare no conflict of interest.

For citations: Khleborodov A.Ya., Pochitskaya I.M Provotorova O.S., Skripkovich P.A. Assortment of pumpkin (Cucurbita pepo L.) of Belarusian selection for the production of pumpkin oil. Vegetable crops of Russia. 2020;(6):41-46. (In Russ.) https://doi.org/10.18619/2072-9146-2020-6-41-46

\section{Резюме}

Актуальность и методика. Плоды и семена тыквы являются ценным сырьем для пищевой и фармакологической промышленности. Особую ценность представляют семена тыквы, из которых получают масло и белковые продукты. Цель наших исследований выделить лучшие селекционные образцы твердокорой тыквы по выходу семян и тыквенного масла и изучить их биохимический состав. Проведена оценка 12 образцов твердокорой тыквы по основным хозяйственно-биологическим признакам.

Результаты. По урожайности семян и выходу тыквенного масла выделились следующие образцы: Дельта, Голосемянно-кустовая, Линия 2-3, Линия 2-5. Изучен биохимический состав образцов семян с высокой урожайностью семян по содержанию белков, жиров, углеводов, аминокислот, жирных кислот, витаминов и минеральных веществ. Проведен биохимический анализ тыквенного масла по жирным кислотам, стеринам и минеральным веществам. Семена твердокорой тыквы белорусской селекции источники высокого содержания белка (34-35\%) с широким спектром незаменимых аминокислот, жиров (43-45,8\%), ненасыщенных и насыщенных жирных кислот, а также углеводов $(9,6$ $11,9 \%)$, ряда витаминов, макро- и микроэлементов.

Ключевые слова: тыква, сортообразцы, семена, тыквенное масло

\section{Assortment of pumpkin (Cucurbita pepo L.) of Belarusian selection for the production of pumpkin oil}

\section{Abstract}

Relevance and methods. Pumpkin fruits and seeds are valuable raw materials for the food and pharmaceutical industries. Of particular value are pumpkin seeds, from which oil and protein products are obtained. The purpose of our research is to identify the best breeding samples of pumpkin in terms of seed yield and pumpkin oil and to study their biochemical composition. The evaluation of 12 samples of pumpkin was carried out according to the main economic and biological characteristics.

Results. According to the yield of seeds and the yield of pumpkin oil, the following samples were distinguished: Delta, Golosemyanno-kustovaya, Line 2-3, Line 2-5. The biochemical composition of seed samples with high seed yields was studied in terms of the content of proteins, fats, carbohydrates, amino acids, fatty acids, vitamins and minerals. A biochemical analysis of pumpkin seed oil for fatty acids, sterols and minerals was carried out. Seeds of hard-barked pumpkin of Belarusian selection are sources of high protein content (34-35\%) with a wide range of essential amino acids, fats (43-45.8\%), unsaturated and saturated fatty acids, as well as carbohydrates $(9.6-11.9 \%)$, a number of vitamins, macro- and microelements.

Keywords: Cucurbita pepo L., variety, seeds, pumpkin oil 


\section{Введение}

лоды и семена тыквы являются ценным сырьем для пищевой и фармакологической промышленности. Особую ценность представляют семена тыквы, из которых получают масло и белковые продукты. Масло тыквы используют не только как пищевой продукт, но и для производства различных фармакологических препаратов.

Диетическая ценность масла из семян тыквы обусловлена высоким содержанием в нем необходимых ненасыщенных жирных кислот, которые объединены в витаминный фактор «F». При их недостатке в организме человека возникают такие заболевания как атеросклероз и злокачественные новообразования. Суточная потребность человека в ненасыщенных жирных кислотах составляет 3-6 г [1]. В связи с этим потребности пищевой промышленности и фармакологии в растительных маслах, к которым относится и тыквенное масло, будут возрастать [2, 3, 4].

Мировым лидером по производству и экспорту тыквенного масла является Австрия. В Европейском Союзе стоимость 1 л тыквенного масла составляет $40 \$$.

Цель наших исследований - выделить лучшие селекционные образцы твердокорой тыквы по выходу семян и тыквенного масла и изучить их биохимический состав.

\section{Материалы и методы}

Объектом исследований являлись семена и тыквенное масло. Для получения семян и учета их урожайности опыты закладывали в овощном севообороте.

Почва опытного участка - лессовидные суглинки и супеси, сформированные на моренных флювиогляциальных отложениях, содержит 240-300 мг/кг $\mathrm{P}_{2} \mathrm{O}_{5}, 260-300$ мг/кг $\mathrm{K}_{2} \mathrm{O}$, гумуса 2,2-2,7\%. Кислотность почвы близка к нейтральной - pHKCL 6,2-6,6. Перед посевом в почву вносили минеральные удобрения в следующем количестве действующего вещества: $\mathrm{N}_{90} \mathrm{P}_{90} \mathrm{~K}_{120}$ кг/га.

Семена высевали в оптимальные агротехнические сроки, в третьей декаде мая, при прогревании пахотного горизонта почвы до $14 \ldots 15^{\circ} \mathrm{C}$. Длинноплетистые образцы тыквы сеяли по схеме 210x140 см, а короткоплетистые 140x140 см. Повторность закладки опытов трехкратная. В качестве стандарта высевали районированный сорт твер- докорой тыквы Дельта. Учет урожая плодов и семян проводили путем их взвешивания.

Семена из плодов поделяночно выделяли вручную, в стадии полной технической спелости и сушили при температуpe $25 . .30^{\circ} \mathrm{C}$, на электрокалорифере до 8-12\% влажности.

Оценка физико-химических показателей семян тыквы и масла проведена в РУП «НПЦ НАН Беларуси по продовольствию» в соответствии с методическими рекомендациями нормативно-правовых актов ТНПА, установленными в области технического нормирования и стандартизации.

В лабораторных условиях масло из семян тыквы получали методом холодного отжима на прессе голландской фирмы «Piteba». Промышленный отжим тыквенного масла осуществляли в агрофирме ООО «Примаоил» г. Смолевичи, Минского района, Минской области.

Статистическая обработка опытных данных проведена по Доспехову Б.А. [5] и с использованием компьютерных программ

\section{Результаты и их обсуждение}

В 2016-2019 годах проведена оценка исходных образцов твердокорой тыквы белорусской селекции на урожайность семян. В результате проделанной работы были выявлены сорта и линии, обладающие высокой урожайностью плодов, выходом семян, скороспелостью и различным габитусом строения куста. По урожайности плодов и выходу семян выделились следующие сорта: Дельта, Голосемянно-плетистая, Голосемянно-кустовая, а из линий: 2-5; 2-3 и 2-2 (табл. 1).

Продолжительность вегетационного периода изучаемых образцов, до периода созревания плодов, составляло 90100 дней. По признаку скороспелости (90 дней) выделились сорта и линии кустового габитуса.

Сорта и линии различались по массе плода. Наибольшую массу плода имел районированный в Беларуси сорт Дельта. У этого сорта признак (масса плода) варьировал от 3 до 8 кг. В сравнении со стандартом, у других сортов и линий масса плода была меньше в 1,5-2 раза.

Форма и окраска плода у сортов и линий контрастно подразделялась на два типа соответственно: овальная и шаровидная, оранжевая и желто-зеленая.

Таблица 1. Оценка исходных образцов твердокорой тыквы (Cucurbita pepo L.) белорусской селекции по основным хозяйственно-биологическим признакам

Table 1. Assessment of the original samples of pumpkin (Cucurbita pepo L.) of the Belarusian selection for the main economic and biological characteristics

\begin{tabular}{|c|c|c|c|c|c|c|c|c|c|}
\hline \multirow{2}{*}{ Название } & \multicolumn{2}{|c|}{ Урожайность } & \multirow{2}{*}{$\begin{array}{c}\text { Выход } \\
\text { семян, \% }\end{array}$} & \multirow{2}{*}{$\begin{array}{c}\text { Скороспелость, } \\
\text { дней }\end{array}$} & \multirow{2}{*}{$\begin{array}{l}\text { Габитус } \\
\text { куста }\end{array}$} & \multicolumn{3}{|c|}{ Плод } & \multirow{2}{*}{$\begin{array}{c}\text { Наличие } \\
\text { кожуры } \\
\text { у семян } \\
\text { (+ имеется, } \\
\text { - отсутствует) }\end{array}$} \\
\hline & $\begin{array}{c}\text { плодов, } \\
\text { т/га }\end{array}$ & $\begin{array}{c}\text { семян, } \\
\text { ц/га }\end{array}$ & & & & $\begin{array}{c}\text { мacca, } \\
\text { кr }\end{array}$ & форма & окраска & \\
\hline Дельта (стандарт) & 65 & 6,50 & 1,00 & 100 & плетистая & $3,0-8,0$ & овальная & оранжевая & + \\
\hline Голосемянно-плетистая & 55 & 9,90 & 1,80 & 95 & плетистая & $2,5-5,0$ & овальная & оранжевая & - \\
\hline Голосемянно- кустовая & 50 & 10,00 & 2,00 & 90 & кустовая & $1,8-4,0$ & шаровидная & оранжевая & - \\
\hline Линия 1-1 & 48 & 10,08 & 2,10 & 95 & плетистая & $1,5-4,0$ & овальная & оранжевая & + \\
\hline Линия 2-1 & 51 & 11,22 & 2,20 & 95 & плетистая & $2,0-4,5$ & овальная & оранжевая & - \\
\hline Линия 2-2 & 53 & 12,72 & 2,40 & 95 & плетистая & $2,5-5,0$ & овальная & оранжевая & - \\
\hline Линия 2-3 & 54 & 15,12 & 2,80 & 95 & плетистая & $2,3-4,8$ & овальная & $\begin{array}{c}\text { желто- } \\
\text { зеленая }\end{array}$ & - \\
\hline Линия 2-4 & 52 & 13,00 & 2,50 & 95 & плетистая & $2,0-4,0$ & овальная & $\begin{array}{c}\text { желто- } \\
\text { зеленая }\end{array}$ & - \\
\hline Линия 2-5 & 55 & 14,30 & 2,60 & 90 & кустов. & $2,5-3,0$ & шаровидная & $\begin{array}{c}\text { желто- } \\
\text { зеленая }\end{array}$ & - \\
\hline Линия 2-6 & 49 & 11,27 & 2,30 & 90 & кустовая & $2,6-3,2$ & шаровидная & оранжевая & - \\
\hline Линия 2-7 & 51 & 7,65 & 1,50 & 90 & кустовая & $2,8-4,0$ & шаровидная & оранжевая & + \\
\hline Линия 2-8 & 50 & 9,00 & 1,80 & 90 & кустовая & $2,6-4,3$ & шаровидная & $\begin{array}{c}\text { желто- } \\
\text { зеленая }\end{array}$ & + \\
\hline
\end{tabular}


При получении из семян тыквенного масла большое значение имеет наличие или отсутствие кожистой оболочки у семян [6]. Четыре исходных образца коллекции были с кожистой оболочкой, а у восьми она отсутствовала.

Относительно процента выхода семян из плодов следует отметить, что наибольший показатель был характерен для голосемянных сортов и линии кустового и плетистого габитуса. По этому признаку превышение над стандартом составило 1,5-2,8 раза.

В селекции твердокорой тыквы урожайность семян определяли наличие корреляционных связей между массой плода и наличием в нем семян. В результате проделанной работы было установлено, что между массой плода, массой семян, их количеством в плоде, процентом выхода семян существует обратная корреляционная зависимость соответственно: $r=-0,52 ; r=-0,65 ; r=-0,87$, то есть, количественные показатели по семенам убывают [7]. Эта особенность связана с размером (толщиной) мезокарпия. При его увеличении (разрастании) размер семенной камеры уменьшается, при этом убывает масса семян и их количество в плоде.

Высокие показатели прямой корреляционной зависимости существуют между массой семян в плоде и количеством семян $r=0,84$, а также между массой семян в плоде и процентом выхода семян $r=0,78$. Средний показатель корреляционной зависимости существует между массой семян в плоде и массой 1000 семян: $r=0,46[7]$.

Сорта и линии твердокорой тыквы белорусской селекции обладают высокой урожайностью семян, между которыми имеются различия по морфологическим признакам и химическому составу.

Содержание в семенах белка, незаменимых аминокислот, жиров и ненасыщенных жирных кислот, углеводов, витаминов, минеральных веществ, является основным показателем их питательной ценности.

По массовой доле белков, изученные образцы тыквы не уступают другим видам масличных культур, таких как подсолнечник, лен и рапс. В семенах этих культур содержится 18-20\% белка. Содержание массовой доли белка у образцов тыквы белорусской селекции 33,9-35,9\% (табл. 2). Варьирование показателей по белку между образцами тыквы составило 2,24\%.

Анализ аминокислотного состава белков семян тыквы показал, что белковые фракции содержат широкий спектр аминокислот, включая незаменимые, такие как гистидин, треонин, аланин, валин, метионин, фенилаланин, изолейцин, лейцин, лизин. Показатель коэффициента варьирования (V, \%), незаменимых аминокислот среди изученных образцов тыквы, колебался в пределах 3,5-8,18\%. Из частично заменимых аминокислот наиболее высокий показатель коэффициента варьирования отмечен по глицину $(\mathrm{V}=30,44 \%)$. Относительно содержания частично заменимых аминокислот, таких как аргинин, тирозин, цистин, показатель коэффициента варьирования был невысоким и колебался от 3,4\% до 4,34\%. Варьирование аминокислотного состава семян образцов тыквы по заменимым аминокислотам: аспартат, глутамат, серин, аланин также было сравнительно низким - в пределах 4,8-6,27\%.

Жиры, содержащиеся в семенах различных видов масличных культур, называются маслами, поскольку после их извлечения из семян они обладают жидкой консистенцией [8]. В семенах изученных образцов твердокорой тыквы белорусской селекции содержание жиров колебалось в пределах $43 \div 45,2 \%$. В целом по масличности семена тыквы не уступают таким культурам как рапс (40-44\%), лен (40-50\%) и подсолнечник (40-52\%).

Показатели массовой доли содержания жира и жирных кислот в семенах твердокорой тыквы белорусской селекции представлены в таблице 2.
Жиры состоят из глицеридов насыщенных и ненасыщенных жирных кислот. В продуктах растительного происхождения в основном преобладают пальмитиновая, олеиновая, линолевая и линоленовая кислоты.

В семенах изученных образцов твердокорой тыквы белорусской селекции больше всего было обнаружено следующих видов жирных кислот: линолевой, олеиновой, пальмитиновой и стеариновой. Особую ценность представляют ненасыщенные (непредельные) жирные кислоты, которые обладают высокой биологической активностью. В организме человека эти жирные кислоты не образуются и должны обязательно поступать с пищей. При их недостатке в пище нарушаются процессы обмена веществ, поэтому эти кислоты относятся к витаминам группы F.

Коэффициент варьирования по содержания жира в семенах среди изученных образцов твердокорой тыквы составил $\mathrm{V}=1,83 \%$, а по содержанию непредельных (ненасыщенных) жирных кислот: линолевой - V=2,26\%; линоленовой $-\mathrm{V}=4,5 \%$; олеиновой $-\mathrm{V}=9,8 \%$.

Оценка семян образцов тыквы по содержанию ряда других жирных кислот: арахиновой, бегеновой, декозадиеновой, каприловой, каприновой, лауриновой, лигноцериновой, маргариновой, маргаринолеиновой, масляной, миристиновой, нервоновой, пальмитинолеиновой, пентадециловой, эйкозадиеновой, эруковой и других показала, что их показатели были сравнительно низкими $(<0,1 \%)[9]$

Помимо белков и жиров семена тыквы содержат углеводы и ряд витаминов. Массовая доля углеводов в семенах образцов твердокорой тыквы белорусской селекции колеблется в пределах 9,6-11,9\%. Коэффициент варьирования углеводов среди образцов тыквы составил 8,32\%. Изучен биохимический состав семян в отношении содержания витаминов $\mathrm{B}_{1}, \mathrm{~B}_{2}, \mathrm{~B}_{6}$ и $\beta$-каротина (провитамин «A») (табл. 2). Выявлено наибольшее варьирование показателей в содержании витамина В1 при коэффициенте варьирования $\mathrm{V}=45,53 \%$, а также $\beta$-каротина - V=38,1\%. Высокий процент содержания $\beta$-каротина характерен для сортов и линий голосемянного типа - Голосемянно-плетистая (1,31 мг/100 г); Голосемянно-кустовая (0,82 мг/100 г); Линия 2-4 (1 мг/ 100 г) и Линия 2-5 (0,9 мг/100 г).

Содержание других витаминов группы «В»- рибофлавина $\left(\mathrm{B}_{2}\right)$ и пиридоксина $\left(\mathrm{B}_{6}\right)$, в семенах образцов тыквы низкое (табл. 2).

Минеральные вещества, к которым относятся неорганические элементы и их соли, необходимы для человеческого организма в такой же степени как белки, жиры и углеводы, поскольку они присутствуют во всех тканях и участвуют в осуществлении разнообразных процессах по обмену веществ.

Все необходимые для человека и животных минеральные вещества доставляются с пищей и только одно вещество - хлористый натрий - добавляют к пищевым продуктам.

Семена образцов твердокорой тыквы обладают высоким содержанием ряда макро- и микроэлементов. Отмечено наиболее высокое содержание в семенах следующих макроэлементов: фосфора, калия, магния, кальция и железа, а из микроэлементов - цинка, марганца и меди (табл. 2).

Из результатов оценки, судя по коэффициенту вариации (V, \%), отмечено наиболее широкое их варьирование среди сортообразцов по натрию (V=81,33\%); калию

$(\mathrm{V}=23,29 \%)$; цинку ( $\mathrm{V}=22,8 \%) ;$ кальцию $(\mathrm{V}=19,34 \%) ;$ железу (V=17,6\%); марганцу (V=13\%) и фосфору ( $\mathrm{V}=11,38 \%)$.

Семена тыквы являются перспективным сырьем для получения масла и побочного высокобелкового продукта жмыха [10]. Процент выхода тыквенного масла из семян 
Таблица 2. Химический состав семян твердокорой тыквы белорусской селекции.

Table 2. The chemical composition of seeds of hard-barked pumpkin of Belarusian selection

\begin{tabular}{|c|c|c|c|c|c|c|}
\hline Признак & Дельта & $\begin{array}{c}\text { Голосемянно- } \\
\text { плетистая }\end{array}$ & $\begin{array}{c}\text { Голосемянно- } \\
\text { кустовая }\end{array}$ & $\begin{array}{c}\text { Линия } \\
2-3\end{array}$ & $\begin{array}{c}\text { Линия } \\
2-4\end{array}$ & $\begin{array}{c}\text { Линия } \\
2-5\end{array}$ \\
\hline \multicolumn{7}{|c|}{ Физико-химические показатели, \% } \\
\hline Влажность & 5,30 & 5,60 & 5,40 & 5,50 & 5,50 & 5,30 \\
\hline Зольность & 5,40 & 5,05 & 5,24 & 4,79 & 4,78 & 4,76 \\
\hline Массовая доля белка & 33,90 & 34,20 & 34,00 & 35,00 & 35,90 & 35,10 \\
\hline Массовая доля жира & 45,20 & 43,30 & 44,60 & 44,10 & 44,20 & 43,00 \\
\hline Массовая доля углеводов & 10,20 & 11,90 & 10,80 & 10,60 & 9,60 & 11,80 \\
\hline \multicolumn{7}{|c|}{ Аминокислотный состав, мг/100 г } \\
\hline Аспартат & 863,10 & 838,40 & 787,30 & 769,00 & 769,80 & 745,50 \\
\hline Глутамат & 2587,10 & 2434,10 & 2308,30 & 2283,00 & 2258,30 & 2175,80 \\
\hline Серин & 701,90 & 675,90 & 669,20 & 640,00 & 642,90 & 612,50 \\
\hline Гистидин & 28,90 & 30,10 & 29,70 & 26,70 & 27,70 & 26,80 \\
\hline Глицин & 1300,80 & 1307,30 & 1354,60 & 685,50 & 1292,10 & 650,00 \\
\hline Треонин & 53,20 & - & - & - & - & - \\
\hline Аргинин & 2216,80 & 2118,00 & 2087,20 & 2093,80 & 2041,60 & 1976,00 \\
\hline Аланин & 746,60 & 763,70 & 723,90 & 710,00 & 684,10 & 659,80 \\
\hline Тирозин & 352,90 & 355,60 & 336,20 & 336,00 & 330,80 & 328,20 \\
\hline Цистин & 1633,70 & 1658,40 & 1837,80 & 1732,00 & 1775,90 & 1735,40 \\
\hline Валин & 209,10 & 206,80 & 193,20 & 190,60 & 186,30 & 175,80 \\
\hline Метионин & 507,50 & 479,40 & 485,50 & 484,80 & 475,00 & 454,40 \\
\hline Фенилаланин & 575,80 & 550,50 & 526,60 & 513,10 & 504,40 & 491,70 \\
\hline Изолейцин & 188,40 & 190,40 & 178,20 & 172,50 & 170,00 & 163,50 \\
\hline Лейцин & 3285,30 & 3226,80 & 3065,00 & 3058,60 & 2921,30 & 2921,30 \\
\hline Лизин & 715,20 & 774,40 & 655,90 & 706,60 & 615,90 & 655,80 \\
\hline \multicolumn{7}{|c|}{ Массовая доля жирных кислот, \% } \\
\hline Пальмитиновая & 10,70 & 10,10 & 9,90 & 8,60 & 8,70 & 9,20 \\
\hline Стеариновая & 3,90 & 5,80 & 6,20 & 5,30 & 5,30 & 5,40 \\
\hline Олеиновая & 20,10 & 15,10 & 18,60 & 16,90 & 16,80 & 18,10 \\
\hline Линолевая & 63,80 & 66,30 & 63,60 & 67,20 & 66,50 & 65,40 \\
\hline Линоленовая & 0,20 & 0,30 & 0,30 & 0,20 & 0,20 & 0,20 \\
\hline Гондоиновая & 0,30 & 0,40 & 0,40 & 0,30 & 0,30 & 0,30 \\
\hline \multicolumn{7}{|c|}{ Витамины, мг/100 г } \\
\hline Массовая доля витамина В & 0,29 & 0,28 & 0,33 & 0,08 & 0,14 & 0,17 \\
\hline $\begin{array}{l}\text { Массовая концентрация } \beta \text { - } \\
\text { каротина, мг/100 г }\end{array}$ & 0,35 & 1,31 & 0,82 & 0,70 & 1,00 & 0,90 \\
\hline \multicolumn{7}{|c|}{ Минеральный состав, мг/кг } \\
\hline Кальций & 388,00 & 343,00 & 352,00 & 280,00 & 465,00 & 470,00 \\
\hline Магний & 3080,00 & 2955,00 & 3020,00 & 2675,00 & 3500,00 & 3375,00 \\
\hline Фосфор & 11100,00 & 9370,00 & 10050,00 & 9340,00 & 12350,00 & 11350,00 \\
\hline Марганец & 37,00 & 37,00 & 39,00 & 31,00 & 45,00 & 44,00 \\
\hline Медь & 16,00 & 14,00 & 14,00 & 13,00 & 14,00 & 14,00 \\
\hline Железо & 61,00 & 64,00 & 67,00 & 60,00 & 87,00 & 87,00 \\
\hline Цинк & 72,00 & 53,00 & 51,00 & 50,00 & 80,00 & 81,00 \\
\hline Калий & 7755,00 & 9460,00 & 9640,00 & 8950,00 & 9270,00 & 9380,00 \\
\hline Натрий & 8,00 & 10,00 & 30,00 & 31,00 & 4,00 & 7,00 \\
\hline
\end{tabular}


Таблица 3. Урожайность семян, масличность сортов и линий твердокорой тыквы белорусской селекции Table 3. Seed productivity, oil content of varieties and lines of hard-barked pumpkin of Belarusian selection

\begin{tabular}{|c|c|c|c|c|c|}
\hline \multirow{2}{*}{$\begin{array}{c}\text { Название } \\
\text { сортов } \\
\text { и линий }\end{array}$} & \multicolumn{2}{|c|}{ Урожайность } & \multicolumn{2}{|c|}{ Выход, \% } & \multirow{2}{*}{$\begin{array}{c}\text { Количество } \\
\text { масла, } \\
\text { кг/га }\end{array}$} \\
\hline & $\begin{array}{c}\text { плодов, } \\
\text { т/га }\end{array}$ & $\begin{array}{c}\text { семян, } \\
\text { ц/га }\end{array}$ & семян & масла & \\
\hline Дельта & 65 & 6,50 & 1,0 & 40,0 & 260,0 \\
\hline Голосемянно-плетистая & 55 & 9,90 & 1,8 & 33,3 & 330,0 \\
\hline Голосемянно-кустовая & 50 & 10,00 & 2,0 & 36,6 & 366,6 \\
\hline Линия 2-3 & 54 & 15,12 & 2,8 & 40,0 & 604,8 \\
\hline Линия 2-4 & 52 & 13,00 & 2,5 & 33,3 & 433,3 \\
\hline Линия 2-5 & 55 & 14,30 & 2,6 & 46,6 & 667,3 \\
\hline
\end{tabular}

сортообразцов белорусской селекции находился в пределах 33,3-46,6\% (табл.3).

Высокий процент выхода тыквенного масла характерен для голосемянных линий 2-3 и 2-5, а также у стандартного сорта тыквы Дельта, у которого ядро семени покрыто твер- дой кожистой оболочкой. В сравнении со стандартом Линия 2-5 по выходу тыквенного масла превышала его на $16,5 \%$.

В результате изучения физико-химического и жирнокислотного состава масла было установлено, что оно отно-

Таблица 4. Результаты биохимического анализа тыквенного масла Table 4. Results of biochemical analysis of pumpkin oil

\begin{tabular}{|c|c|c|c|c|c|c|}
\hline \multirow[b]{2}{*}{ Показатели } & \multicolumn{6}{|c|}{ Образцы } \\
\hline & Дельта & $\begin{array}{c}\text { Голосемянно- } \\
\text { плетистая }\end{array}$ & $\begin{array}{l}\text { Голосемянно- } \\
\text { кустовая }\end{array}$ & $\begin{array}{c}\text { Линия } \\
2-3\end{array}$ & $\begin{array}{c}\text { Линия } \\
2-4\end{array}$ & $\begin{array}{c}\text { Линия } \\
2-5\end{array}$ \\
\hline Влага и летучие вещества, \% & 0,05 & 0,01 & 0,01 & 0,01 & 0,03 & 0,02 \\
\hline $\begin{array}{l}\text { Массовая доля } \\
\text { жирных кислот, \% } \\
\text { Линолевая }\end{array}$ & 64,6 & 67,9 & 65,5 & 65,4 & 65,4 & 64,5 \\
\hline Олеиновая & 19,7 & 17 & 17,4 & 17,3 & 17,4 & 18,7 \\
\hline Пальмитиновая & 10,7 & 8,5 & 10,2 & 10,3 & 10,2 & 9,9 \\
\hline Стеариновая & 3,8 & 5,2 & 5,9 & 6 & 5,9 & 5,5 \\
\hline Арахиновая & 0,3 & 0,3 & 0,3 & 0,3 & 0,3 & 0,3 \\
\hline Гондоиновая & 0,3 & 0,3 & 0,3 & 0,3 & 0,3 & 0,3 \\
\hline Линоленовая & $<0,2$ & $<0,2$ & $<0,2$ & $<0,2$ & $<0,2$ & $<0,2$ \\
\hline Арахидоновая & 0,3 & 0,3 & 0,3 & $<0,2$ & $<0,2$ & $<0,2$ \\
\hline Декозагексаеновая & 0,3 & 0,5 & $<0,2$ & $<0,2$ & $<0,2$ & 0,5 \\
\hline Эйкозатриеновая & $<0,2$ & $<0,2$ & $<0,2$ & 0,4 & 0,4 & 0,4 \\
\hline Декозадиеновая & $<0,2$ & $<0,2$ & $<0,2$ & $<0,2$ & $<0,2$ & $<0,2$ \\
\hline Нервоновая & $<0,2$ & $<0,2$ & $<0,2$ & $<0,2$ & $<0,2$ & $<0,2$ \\
\hline Бегеновая & $<0,2$ & $<0,2$ & $<0,2$ & $<0,2$ & $<0,2$ & $<0,2$ \\
\hline Эруковая & $<0,2$ & $<0,2$ & $<0,2$ & $<0,2$ & $<0,2$ & $<0,2$ \\
\hline Масляная & $<0,2$ & $<0,2$ & $<0,2$ & $<0,2$ & $<0,2$ & $<0,2$ \\
\hline Капроновая & $<0,2$ & $<0,2$ & $<0,2$ & $<0,2$ & $<0,2$ & $<0,2$ \\
\hline Каприловая & $<0,2$ & $<0,2$ & $<0,2$ & $<0,2$ & $<0,2$ & $<0,2$ \\
\hline Каприновая & $<0,2$ & $<0,2$ & $<0,2$ & $<0,2$ & $<0,2$ & $<0,2$ \\
\hline Лауриновая & $<0,2$ & $<0,2$ & $<0,2$ & $<0,2$ & $<0,2$ & $<0,2$ \\
\hline Миристиновая & $<0,2$ & $<0,2$ & $<0,2$ & $<0,2$ & $<0,2$ & $<0,2$ \\
\hline Пентадециловая & $<0,2$ & $<0,2$ & $<0,2$ & $<0,2$ & $<0,2$ & $<0,2$ \\
\hline Пальметинолеиновая & $<0,2$ & $<0,2$ & $<0,2$ & $<0,2$ & $<0,2$ & $<0,2$ \\
\hline Маргариновая & $<0,2$ & $<0,2$ & $<0,2$ & $<0,2$ & $<0,2$ & $<0,2$ \\
\hline Маргаринолеиновая & $<0,2$ & $<0,2$ & $<0,2$ & $<0,2$ & $<0,2$ & $<0,2$ \\
\hline $\begin{array}{l}\text { Стерины, мкг/г: } \\
\text { Бета-ситостерин }\end{array}$ & 254,1 & 306,2 & 223,1 & 363,1 & 447,8 & 565 \\
\hline Брассикастерин & не обнаружено & не обнаружено & не обнаружено & не обнаружено & не обнаружено & не обнаружено \\
\hline Кампастерин & не обнаружено & не обнаружено & не обнаружено & не обнаружено & не обнаружено & не обнаружено \\
\hline Стигмастерин & не обнаружено & не обнаружено & не обнаружено & не обнаружено & не обнаружено & не обнаружено \\
\hline $\begin{array}{l}\text { Минеральный } \\
\text { состав, мг/кг: Сa }\end{array}$ & 23 & 14 & 11 & 14 & 14 & 18 \\
\hline Mg & 19 & 3,5 & 4,9 & 8,9 & 4,6 & 6,4 \\
\hline $\mathbf{P}$ & 49 & 14 & 17 & 24 & 15 & 18 \\
\hline K & 22 & $<1$ & 2,4 & 4,1 & $<1$ & 1,3 \\
\hline $\mathrm{Na}$ & 6,3 & $<1$ & 2,7 & 5,3 & 3,7 & 5 \\
\hline Mn & 0,23 & 0,06 & 0,05 & 0,08 & 0,06 & 0,1 \\
\hline $\mathrm{Fe}$ & 4,71 & 1,16 & 0,76 & 0,66 & 1,14 & 1,52 \\
\hline $\mathrm{Cu}$ & 0,11 & 0,03 & 0,05 & 0,05 & 0,02 & 0,07 \\
\hline $\mathrm{Zn}$ & 2,15 & 1,08 & 1,54 & 0,96 & 0,61 & 1,04 \\
\hline
\end{tabular}


сится к пищевым маслам. Содержание влаги и летучих веществ в масле находится в пределах 0,01-0,05\%. Качество тыквенного масла определяется составом ненасыщенных и насыщенных жирных кислот, их количественным соотношением. Из ненасыщенных жирных кислот в составе тыквенного масла преобладают линолевая и олеиновая, а из насыщенных - пальмитиновая и стеариновая (табл.4). Все остальные жирные кислоты содержатся в сравнительно небольшом количестве: от 0,2 до 0,3\%.

Тыквенное масло содержит ряд макро- и микроэлементов соответственно: фосфор - 14-49 мг/кг; калий - 1-22 мг/кг; магний - 3,5-19 мг/кг; кальций - 11-23 мг/кг; натрий - 1-6,3 мг/кг; железо - 0,76-4,71 мг/кг; цинк - 0,61-2,15 мг/кг; марганец - 0,05-0,23 мг/кг; медь - 10,02-0,11 мг/кг.

Из числа стеринов в тыквенном масле присутствует бета-ситостерин в количестве 223,1-565,0 мкг/г. Ситостерин играет важную роль в биохимических процесcax, поскольку блокирует действие ряда ядовитых веществ, связывает токсины, участвует в образовании ряда биологически активных веществ [8].

\section{Заключение}

1. По комплексу хозяйственно-биологических признаков выделились следующие сортообразцы: Дельта, Голосемянно-плетистая, Голосемянно-кустовая, Линия 2-3, Линия 2-4, Линия 2-5.

2. Высокий процент выхода семян из плодов имеют голосемянные образцы тыквы: Линия 2-3; Линия 2-4; Линия 2-5.

3. Содержание массовой доли белка в семенах выделившихся сортов и линий составляло 34-35\%, при коэф-

\section{Об авторах:}

Анатолий Яковлевич Хлебородов - кандидат С.-Х. наук,

заведующий сектора тыквенных овощных культур, cucurbita@belniio.by

Ирина Михайловна Почицкая - кандидат с.-х. наук, начальник

Республиканского контрольно-испытательного комплекса

по качеству и безопасности продуктов питания, rkik-npc@mail.ru

Ольга Станиславовна Провоторова - научный сотрудник

сектора тыквенных овощных культур, ol_provotorova@mail.ru

Полина Александровна Скрипкович - инженер-химик

\section{- Литература}

1. Покровский А.А., Савощенко И.С. Лечебное питание. М:, 1974. 400 с. 2. Деревенко В.В. Научное обоснование и разработка ресурсосберегающих процессов производства растительных масел и создание конкурентоспособной промышленной аппаратуры: автореф. дис. на соиск. уч.ст. доктора техн. наук. СиП, 2007. 48 с.

3. Nakic J., Rade D., Jkesin D., Jtruselj D., Mokrosack Z., Brtolic M. Chevica characteristics of oils from naked fnd husk seeds of Cucurbita pepo L. Eur. J. Lipid. Sci. Technol. - 2006;(108):936-943.

4. Ханфар Раэд. Тыквенные семена - перспективный источник пищевого белка. Изв. вузов. Пищевая технология. 2005;(5-6):44-46.

5. Доспехов Б.А. Методика полевого опыта. 1985. 351 с.

6. Фурса, Т.Б., Филов А.И. Тыквенные (арбуз, тыква). М.: Колос, 1982. 279

с. (Культурная фолора СССР; Т. 21.

7. Хлебородов, А.Я., Гребенникова Л.Ю., Провоторова О.С. Селекция голосемянной тыквы (Cucurbita pepo L. var. styriaca) в Беларуси Овощеводство: сб. науч. тр. Нац. акад. наук Беларуси, РУП «Ин-т овощеводства»; редкол.: А.И. Чайковский (гл. ред.) [и др.]. - Минск, 2016;(24):167-176.

8. Сорвачев К.Ф. Биологическая химия. М: «Просвещение», 1970. 432 с.

9. Хлебородов, А.Я., Почицкая И.М., Провоторова О.С., Юденко А.Н. Семенная продуктивность сортов и линий твердокорой тыквы (Cucurbita реро L.) белорусской селекции и физико-химические показатели семян для производства тыквенного масла. Овощеводство: сб. науч. тр. Нац. акад. наук Беларуси, РУП «Ин-т овощеводства»; редкол.: А.И. Чайковский (гл. ред.) [и др.]. Минск, 2018;(26):186-197.

10. Хлебородов, А.Я., Почицкая И.М., Провоторова О.С., Скрипкович П.А Физико-химические показатели тыквенного масла сортов и линий твердокорой тыквы (Cucurbita pepo L.), белорусской селекции. Земледелие u защита растений. 2018. 47-52 с. фициенте вариации (V=2,24\%). Белковая фракция содержит широкий спектр незаменимых аминокислот: гистидин, треонин, аланин, валин, метионин, фенилаланин, изолейцин, лейцин, лизин при показателе коэффициента их вариации ( $\mathrm{V}=3,5-8,18 \%)$. По содержанию частично заменимых и заменимых аминокислот показатель коэффициента вариации (V, \%) составил 3,4-6,3\%.

4. Содержание жиров в семенах твердокорой тыквы достигало показателя 43-45,2\%, не уступая таким масличным культурам как рапс (40-44\%), лен (40-50\%) и подсолнечник (40-52\%). Из числа жирных кислот в семенах тыквы больше всего содержится линолевой, линоленовой, олеиновой, пальмитиновой и стеариновой кислот.

5. Массовая доля углеводов в семенах находилась в пределах

9,6-11,9\%, при коэффициенте их вариации $\mathrm{V}=8,32 \%$.

6. Из числа витаминов в семенах тыквы больше всего содержится провитамина «А» или $\beta$-каротина и витамина В1 (тиамина).

7. Семена твердокорой тыквы содержат ряд макро- и микроэлементов. Высокое их содержание отмечено по фосфору, калию, магнию и кальцию.

8. По выходу тыквенного масла выделились следующие образцы тыквы: Линия 2-5 - 46,6\%; Линия 2-3 и Дельта - 40\%, превышая стандарт на 16,5\%.

9. В тыквенном масле доминируют ненасыщенные жирные кислоты: линолевая и олеиновая, а из насыщенных - пальмитиновая и стеариновая.

10. Тыквенное масло содержит ряд химических макро- и микроэлементов, бета-ситостерин и витамины.

\section{About the authors:}

Anatoly Ya. Khleborodov - Cand. Sci. (agriculture)

Head of the Pumpkin Vegetable Crops Sector, cucurbita@belniio.by

Irina M. Pochitskaya - Cand. Sci. (agriculture),

Head of the Republican Control and Testing Complex

for Food Quality and Safety, rkik-npc@mail.ru

Olga S. Provotorova - Researcher of the sector

of pumpkin vegetable crops, ol_provotorova@mail.ru

Polina A. Skripkovich - chemical engineer

\section{- References}

1. Pokrovsky A.A., Savoshchenko I.S. Therapeutic nutrition. M., 1974. 400 p. 2. Derevenko V.V. Scientific substantiation and development of resource-saving processes for the production of vegetable oils and the creation of competitive industrial equipment: abstract. dis. for a job. part doctors tech. Science. 2007. $48 \mathrm{p}$.

3. Nakic J., Rade D., Jkesin D., Jtruselj D., Mokrosack Z., Brtolic M. Chevical characteristics of oils from naked fnd husk seeds of Cucurbita pepo L. Eur. J. Lipid. Sci. Technol. - 2006;(108):936-943.

4. Hanfar Raed. Pumpkin seeds are a promising source of dietary protein. RaedHanfar. - Izv. universities. Food Technology. 2005;(5-6):44-46.

5. Dospehov B.A. Methods of field experience. 1985. $351 \mathrm{p}$.

6. Fursa, T.B., Filov A.I. Pumpkin (watermelon, pumpkin). M.: Kolos, 1982. 279 p. (Cultural flora of the USSR; T. 21).

7. Khleborodov, A.Ya., Grebennikova L.Yu., Provotorova O.S. Selection of gymnospermous pumpkin (Cucurbita pepo L. var. styriaca) in Belarus. Nat. Acad. sciences of Belarus, RUE "Institute of vegetable growing"; editorial: A.I. Tchaikovsky (Ch. Ed.) [Et al.ю]. - Minsk, 2016;(24):167-176.

8. Sorvachev K.F. Biological chemistry. M: "Enlightenment", 1970. 432 p.

9. Khleborodov, A.Ya., Pochitskaya I.M., Provotorova O.S., Yudenko A.N. Seed productivity of varieties and lines of hard-barked pumpkin (Cucurbita pepo L.) of Belarusian selection and physicochemical parameters of seeds for the production of pumpkin oil. Vegetable growing: collection. Nat. Acad. sciences of Belarus, RUE "Institute of vegetable growing"; editorial: A.I. Tchaikovsky (Ch. Ed.) [Et al.]. Minsk, 2018;(26):186-197.

10. Khleborodov, A.Ya., Pochitskaya I.M., Provotorova O.S., Skripkovich P.A. Physico-chemical indicators of pumpkin seed oil of varieties and lines of hardbarked squash (Cucurbita pepo L.), Belarusian selection. Agriculture and Plant Protection. 2018. P.47-52 